\title{
Environmental feasibility analysis of heating boiler energy substitution
}

\author{
Dan Ge ${ }^{1, a}$, Xingyu Liu ${ }^{1, b}$, Baiyu Gao ${ }^{3, c}$ and Tong Wang ${ }^{1, d}$ \\ ${ }^{1}$ State Grid Liaoning Electric Power Supply Co. Ltd, Shenyang, China

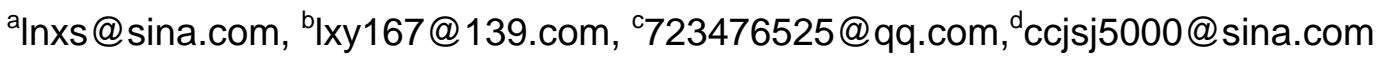

Keywords: Haze; Energy alternative; Environmental protection

\begin{abstract}
The surplus power of Liaoning Province is very obvious, and a lot of spare capacity needs to be consumptive. Haze and other pollution in Liaoning Province take place frequently in winter, and winter heating is one of the major factors. The study found that the implementation of conversion coal to electricity in heating boiler will bring greater spending to the heating companies, one-time renovation subsidies and electricity price subsidies are needed by government. And through environmental analysis, the policy of conversion coal to electricity will reduce one-third emissions in the field.
\end{abstract}

\section{Introduction}

According to the existing installed capacity of Liaoning Province, the full amount of 427.567 billion kwh electricity can be meet in 2013, in which the real production is 257.53 billion kwh, while the total surplus electricity production capacity is 170.037 billion kwh, the percentage of surplus capacity is $39.77 \%$. Surplus production capacity is expected to 139.765 billion kwh in 2014, the percentage of surplus capacity is $36.06 \%$, capacity surplus is obvious also. Among them, the full production capacity within two years of clean energy and heating units are 250.267 billion kwh and 208.827 billion kwh, and the real production are 124.584 billion kwh and 113.73 billion kwh respectively, surplus production capacity are 125.684 billion kwh and 95.098 billion kilowatts when the percentage of surplus capacity are as high as $50.22 \%$ and $45.54 \%$, which have more significant surplus capacity. In 2013 and 2014, the total spare capacity in clean energy and heating units accounted for $73.92 \%$ and $68.04 \%$, which means that most of the remaining capacity are focused on clean energy and heating units. If removing the heating unit, the surplus production capacity of clean energy are 57.872 billion kwh and 66.467 billion kwh within two years, the percentage in the total surplus production capacity are $36.25 \%$ and $32.48 \%$, clean energy surplus still evident.

Based on the above analysis, the surplus electricity of Liaoning is obvious and the clean energy is not fully utilized, the excess capacity needs to be consumed under the security and stability operation premise, to ensure the use of clean energy. The alternative energy strategy of winter heating boiler can achieve effective energy supply security, without increasing the capacity [1-3].

\section{Critical electricity price calculation and correction}

(1) Basic data processing

Taking a heating cycle of 150 days as example, the heating time is $15 \mathrm{~h} /$ day, and the power to maintain $18{ }^{\circ} \mathrm{C} / \mathrm{m} 2$ is $43 \mathrm{~W}$, then per square meter heat requirement of the entire heating cycle is:

$\mathrm{TR}=43 * 15 * 150 / 1000 * 860=83205 \mathrm{kcal}$

According to the total heat requirement, the requirement number of standard coal is:

gc $=83205 / 5000 / 0.7=23.77 \mathrm{~kg}$

0.7 represents the fue efficiency of heating, and 5000 represents 5,000 calories generated by standard coal. If the power efficiency is $98 \%$, the power required per square meter of heating cycle is: $\mathrm{de}=43 * 15^{*} 150 / 1000 / 0.98=98.7244898^{\circ}$

The boiler boiler is 10 tons, heating area is $66,700 \mathrm{~m} 2$, the price of coal is 680 yuan / ton, and the cost of a one-time transformation of coal to electricity is 430,000 yuan / ton, equipment life is 25 years. 
(2) Pushing back the critical price according to the heating cost of per square meter

$\mathrm{TCb}=\mathrm{Rn}+\mathrm{et} * \mathrm{Ee}$

Where TCb is the total cost for transform coal to electricity, $\mathrm{Rn}$ is the renovation costs per year, et is the critical price, and Ee is electricity consumption.

Table 1 Critical price calculation table

\begin{tabular}{l|l|c|c|c}
\hline \multirow{2}{*}{ Price (yuan $/ \mathrm{m}^{2}$ ) } & \multicolumn{1}{|c|}{$\begin{array}{c}\text { Total cost } \\
\text { (yuan) }\end{array}$} & $\begin{array}{c}\text { Total electricity } \\
\text { consumption }\end{array}$ & $\begin{array}{c}\text { Equipment life of } \\
25 \text { years }\end{array}$ & $\begin{array}{c}\text { Renovation costs of government } \\
\text { subsidies }\end{array}$ \\
\hline 25 & 1667500 & \multirow{2}{*}{6584624} & 0.227 & 0.253 \\
\cline { 1 - 2 } & 1798899 & 0.247 & 0.273 \\
\hline
\end{tabular}

Values in the table are calculated in accordance with 10 tons of boiler and total 66,700 square meters, one of the heating costs is 25 yuan $/ \mathrm{m} 2$ and the other is 26.97 yuan $/ \mathrm{m} 2$ based on survey data, enterprise coal to electricity equipment life divided into 15 and 25 years, while the cost of a one-time transformation of the critical price subsidized by the government is taken into account also.

At $98 \%$ efficiency, according to the cost of 25 yuan $/ \mathrm{m} 2$, the critical price is 0.227 yuan under 25 -year life, and 0.253 yuan by government subsidies. According to $26.97 \mathrm{yuan} / \mathrm{m} 2$, the critical price is 0.247 yuan under 25-year life, and 0.273 yuan by government subsidies.

In short, in the two cases, the critical price is between 0.227 to 0.247 , and 0.253 to 0.273 by government subsidies. According to the current cost of electricity production, the companies cannot get the price lower than the 0.273 yuan in heating service, the power companies and government subsidies are required.

Although these conclusions above can explain the in non-economic issues about coal to electricity for heating companies to some extent, and explain why the government should subsidize the electricity companies, to further solve the plight of low-cost electricity for heating companies [4]. However, our analysis found that the above formula, the total cost of the left side of the equation contain operation and maintenance costs, while the right side do not contain operation and maintenance costs. So we improved the equation.

(3) Pushing back the critical price according to pure coal costs per square meter

$\mathrm{TCb}=\mathrm{Rn}+\mathrm{et}^{*} \mathrm{Ee}$

Where the TCb deducted labor, utilities, maintenance and other operating expenses, represent the cost of using coal only.

Table 2 Improved calculation table of critical price

\begin{tabular}{c|c|c|c|c}
\hline Price $\left(\right.$ yuan $/ \mathrm{m}^{2}$ ) & $\begin{array}{c}\text { Total cost } \\
\text { (yuan) }\end{array}$ & $\begin{array}{c}\text { Total electricity } \\
\text { consumption }\end{array}$ & $\begin{array}{c}\text { Equipment life of } \\
25 \text { years }\end{array}$ & $\begin{array}{c}\text { Renovation costs of government } \\
\text { subsidies }\end{array}$ \\
\hline 16.16 & 1077872 & \multirow{2}{*}{6584624} & 0.138 & 0.164 \\
\hline 19.72 & 1315324 & & 0.174 & 0.200 \\
\hline
\end{tabular}

The 16.16 yuan under this table is the pure coal cost obtained by $23.77 \mathrm{~kg}$ per square meter for each heating cycle and coal priced 680 yuan/ton. The 19.72 yuan is the pure coal costs by the company preliminary survey data to get rid of other operating costs. Other variables are as the same as table 1.

According to table 2, we found that in the two cases, the critical price is between 0.138 to 0.174 , and 0.164 to 0.200 by government subsidies. According to the current cost of electricity production, the companies cannot get the price lower than the 0.200 yuan in heating service, the power companies and government subsidies are required [5].

In addition, the analysis shows that, in the latter method of relative scientific calculating, the critical price is lower which need a greater subsidy. 


\section{The environmental feasibility analysis of heating boilers energy alternative}

The total coal consumption of Liaoning Province is 15.694 million tons before heating boilers energy alternative $(\mathrm{BH})$, and 10.33 million tons after energy alternative $(\mathrm{AH})$, only $65.82 \%$ of the total coal consumption before energy alternative, the total coal consumption reduced by 5.364 million ton. According to the formula of each pollutant emissions, the emissions and reductions of various pollutants showed in the following table.

Table 3 The comparison of emissions before and after heating boilers energy alternative (kton)

\begin{tabular}{c|c|c|c|c|c|c|c}
\hline & $\mathrm{CO}_{2}$ & Soot & $\mathrm{SO}_{2}$ & $\mathrm{NO}_{X}$ & $\mathrm{CO}$ & Coal ash & Slag \\
\hline $\begin{array}{c}\text { Emission } \\
\text { of BH }\end{array}$ & 3468.5 & 5.2 & 15.4 & 113.5 & 717.4 & 6.6 & 1459.5 \\
\hline $\begin{array}{c}\text { Emission } \\
\text { of AH }\end{array}$ & 2283 & 3.4 & 10.2 & 74.7 & 472.2 & 4.4 & 960.7 \\
\hline $\begin{array}{c}\text { Reduced } \\
\text { emission }\end{array}$ & 1185.5 & 1.8 & 5.2 & 38.8 & 245.2 & 2.3 & 498.8 \\
\hline $\begin{array}{c}\text { Reduced } \\
\text { percentag } \\
\text { e }\end{array}$ & \multicolumn{70}{|c}{$34.17 \%$} \\
\hline
\end{tabular}

Note: Data in the table are based on survey data.

\section{Summary}

Therefore, only from the energy replacement of heating boiler, the surplus electricity production capacity of Liaoning clean energy can fully satisfy the new energy demand brought by energy alternative, without adding any capacity. After carrying out the energy alternative strategy in the field of heating boiler, the government or the power company should give a certain grants to heating company, but the magnitude of subsidies showed some difference by thermal efficiency, the government subsidies-time transformation costs and the discounting life. According to the 25-year period, 98\% thermal efficiency, and one-time transformation cost of government, the critical price ranges from 0.200 to 0.273 . Specific critical price calculation should be precise by the research and statistics of a variety of operating and maintenance costs.

The policy of coal to electric in boiler fields needs a lot of government subsidies which increases the burden on the government, but on the other hand, the social benefits is very significant, and brings one-third reduction of the large amount of emissions (reductions reached 34.17\%) in the entire field of heating boilers. Short aggravation of the financial burden can exchange the high social benefits for energy conservation, and return Liaoning a "blue sky."

\section{References}

[1] F. P. Ramsey, A Mathematical Theory of saving, E economic Journal, Vol. 38, No.152 (1928), pp.543 -559

[2] N. L. Stokey, Are There Limits to Growth? International Economic Review, Vol.39, No.1 (1998), pp.131

[3] J. M. Anderies, Economic Development, Demographics, and Renewable Resources: A dynamical systems Approach, "Environment and Development Economics, Vol. 45, No.8 (2003), pp.219 246

[4] R. M. Solow. A Contribution to the Theory of Economic Growth, "The Quarterly Journal of Economics, Vol.70, No.1 (1956), pp.65 -94

[5] J. Y. Li. China Energy Development Mode C. Economic development. 01, (2011) 